vol. 23, $n^{\circ} 2$ | 2019

Varia

\title{
Pieter Spierenburg. A Personal Appreciation
}

James Sharpe

\section{OpenEdition \\ Journals}

Electronic version

URL: https://journals.openedition.org/chs/2534

DOI: $10.4000 /$ chs.2534

ISSN: 1663-4837

\section{Publisher}

Librairie Droz

Printed version

Date of publication: 18 December 2019

Number of pages: 101-102

ISSN: 1422-0857

\section{Electronic reference}

James Sharpe, "Pieter Spierenburg. A Personal Appreciation", Crime, Histoire \& Sociétés / Crime, History \& Societies [Online], vol. 23, n² | 2019, Online since 06 May 2020, connection on 03 April 2022. URL: http://journals.openedition.org/chs/2534 ; DOI: https://doi.org/10.4000/chs.2534

This text was automatically generated on 3 April 2022.

(C) Droz 


\title{
Pieter Spierenburg. A Personal Appreciation
}

\author{
James Sharpe
}

1 I first met Pieter Spierenburg at the Social History Society of the UK conference in Birmingham in January 1977, where he was giving a presentation along with Herman Diederiks and (if I remember correctly) Sjoerd Faber. Also present was Tim Curtis, at that time the other British scholar researching into crime in early modern England. Tim and I had heard vaguely of the Dutch Group for Criminal Justice History, and were delighted to make contact with three Dutch scholars whose interests and approaches very much chimed with ours.

2 The 1970s were a good time to be an historian of early modern society. In Oxford, where I studied, there was a body of young historians (they did not form a coherent group), many of them supervised by or associated with Keith Thomas, incidentally one of the earliest British historians to refer to Norbert Elias's work. In Cambridge the institutional support for such research was provided by the Cambridge Group for the History of Population and Social Structure, with Peter Laslett (author of the then very influential The World we have Lost) as its presiding genius. As in the Netherlands, what was then regarded as the "new social history" was regarded with scepticism by many historians of an older generation, but again as in the Netherlands (and in other parts of Europe) the opening up of the lived experience of what might loosely be described as ordinary people in the pre-industrial past was to prove an exceptionally exciting and fruitful field of historical research.

3 This initial international contact was cemented and rendered much broader in 1978 (incidentally the year in which both Pieter and I received our doctorates) at the Seventh International Economic History Association Conference at Edinburgh, at which the International Association for the History of Crime and Criminal Justice was founded. I was nominated as UK correspondent to the Association, and was thus pitched into what proved to be a formative period of my professional development. 1978 also saw a conference in Amsterdam to which I was invited, and where I met other members of the Dutch Group, notably Anton Blok, Herman Roodenburg, and 
Herman Bianchi. And, as is reported in Pieter's interview with Tom Daems and René van Swaaningen, the Association was nurtured by the support of the Maison des Sciences de l'Homme at Paris, under the aegis of Maurice Aymard. Throughout the 1980s contacts broadened, and we had the pleasure of meeting such eminent French researchers as Yves and Nicole Castan and Arlette Farge, along with younger scholars from a variety of countries.

Pieter and I shared a working-class background and a number of the attitudes, both social and political, that went with that - I find his opinions on the generality of middle-class student Marxists very similar to mine, although I think I had rather more time that Pieter for Marxism as an intellectual viewpoint. I can recall two episodes from this period in which he and I were involved. The first was that Pieter very kindly translated into Dutch an article I had written on the idea of early modern English vagrants as a criminal class, to be published in the Tijdschrift voor Criminologie. He produced what I have no reason to doubt was an excellent translation, but commented adversely on my tendency to write long sentences. This is something I have tried to amend ever since. This makes the second episode all the more ironic. A friend of mine in York, aware of my research interests, asked me if I knew Pieter. When I replied that I did, she told me that her father worked as a dustjacket designer for Cambridge University Press, and that, as a result of the length of that book's subtitle, he had experienced considerable difficulty in designing the cover for Pieter's The Spectacle of Suffering.

5 As Manon van der Heijden comments in her reflection, Pieter's behaviour could at times be annoying, even bordering on the boorish. His difficulties at operating early in the morning were a source of constant amusement to me (fortunately they never impacted on any event I was presiding over). Other incidents were rather embarrassing. I remember one occasion in Paris when, in a restaurant in which he, I, and other members of the Association were dining, he drew a shocked gasp from a neighbouring table when he asked just for a crème brûlée and a café crème. Sadly for a disciple of Norbert Elias, one feels that Pieter at that stage would not have proved to be much of a success at Versailles.

6 His later academic career was by anybody's criteria a very successful one. Falk Bretschneider documents and comments on his contribution to the history of confinement, and he was subsequently to produce a number of serious and wellregarded publications on the history of violence, a field with which I myself have become involved. I did not always agree with Pieter's interpretations, but like any other serious scholar in the field, I had to engage with them and treat them with some respect. And, as his review of Benoît Garnot's Une histoire du crime passionnel demonstrates, Pieter himself remained engaged with debates in his subject areas until the very end. Mention should also be made here of Pieter's attempt at a synthesis of early modern social history, appearing in its English language form as The Broken Spell: a Cultural and Anthropological History of pre-Industrial Europe, in which Pieter developed a conceptual framework which drew not only on Norbert Elias, but also Max Weber. The book's emphasis on emotions in that culture provides a distinctive slant on the subject.

7 Those of us who were delighted with Pieter's academic success were also delighted with his marriage to Gisèle, which gave him stability and a platform for better appreciating life outside academe. Unfortunately, it was not too long after this marriage that the health issues which were to plague him later in his life first manifested themselves. 
Pieter Spierenburg's death deprived the field of historical criminology of a valued historian. It also deprived many of us of a valued friend.

\section{AUTHOR}

JAMES SHARPE

University of York, UK

jim.sharpe[at]york.ac.uk 